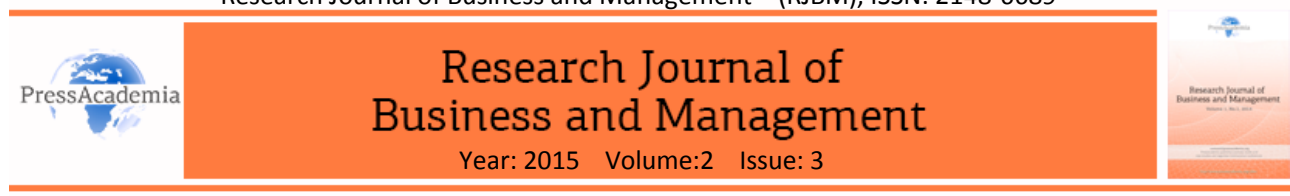

\title{
INTERNAL CAPABILITIES, EXTERNAL SOURCES OF KNOWLEDGE, AND INNOVATIVENESS: AN EMPIRICAL STUDY OF TURKISH MANUFACTURING INDUSTRY
}

\author{
DOI: 10.17261/Pressacademia.2015312988
}

\author{
Arzu Karaman Akgul' \\ ${ }^{1} Y$ ıldız Technical University. akaraman@yildiz.edu.tr
}

\author{
Keywords \\ Innovativeness, \\ internal capabilities, \\ external sources of \\ knowledge, \\ manufacturing \\ industry.
}

JEL Classification 031, 014, M11

\begin{abstract}
Due to the rise of globalization, dynamics of national and international market evolve towards higher competition and uncertainty, necessitating firms to undertake multiple tasks that occur simultaneously. In this difficult to predict atmosphere, using technological opportunities and innovations bring firms a competitive advantage over their rivals. In recent years, one of the significant strategies of gaining and sustaining a competitive advantage in the market is the capability of firms to introduce innovations and adopting these innovations as quickly as possible. Firms mostly use internal capabilities and external sources of knowledge in developing this innovation capability. In the literature, numerous earlier studies have concentrated on the relationship between innovativeness and internal capabilities and external sources of knowledge. However, there are still very few researches on emerging countries which covers all of these dimensions. Therefore, the motivation of this study is to focus on the relationships among internal capabilities of firms, external sources of knowledge, and types of innovations in the case of Turkey as an important emerging country. This study uses a comprehensive model empirically based upon the data gathered from Business Environment and Enterprise Performance Survey (BEEPS) that was carried out by the World Bank in Turkey in 2013. The results show that firms which benefit from internal capabilities are likely to make innovations and firms which use external sources of knowledge are likely to make innovations. But among the types of innovations, only product innovations could be achieved when firms are benefited from the joint effect of internal capabilities and external sources of knowledge.
\end{abstract}

\section{INTRODUCTION}

There is an emphasis on the importance of innovation and related topics in management literature recently. Since innovations affect the competitiveness of firms, the capability of innovativeness has become an important issue and it is investigated by many studies. According to the literature, there are two dominant approaches for sources used in innovation. First approach emphasizes the importance of internal capabilities on innovations which is called as exploitation of existing capabilities (Dosi, 1982), while the other one is stating that innovation is provided by external partners as a main innovation driver and named as the exploration of new possibilities (von Hippel, 1988). The importance of using external sources of knowledge rise due to the increase in technological convergence, the decrease in transaction costs of using external sources of 
knowledge, and shortening product life cycles. Firms that successfully integrate the internal capabilities and external sources of knowledge into their own organization may be more innovative and profitable in today's highly global and competitive environment. Firms therefore need to consider their internal capabilities and external sources of knowledge while evaluating their innovativeness (Lokshin et al. 2008). A new approach, open innovation which is suggested by Chesbrough (2003) for the first time also considers the integration of both internal capabilities and external sources of knowledge into the innovation process. According to this approach, firms need to evaluate all valuable ideas those come from inside and outside of their firm in order to be innovative. Another approach that is suggested by Cohen and Levinthal (1990), emphasized the importance of the ability of firms to realize and adopt the external knowledge repectively, and integrating it to their internal capabilities. This ability is called as the absorptive capacity which is critical to the innovation process.

This study aims to examine the role of internal capabilities and external sources of knowledge on innovation with the help logistic regression method. Based upon the theoretical background of framework of exploitation and exploration (March, 1991), a research model arguing that both internal capabilities and external sources of knowledge affect a firm's innovations. Overall, this study contributes to the literature not only by developing and testing a framework linking internal capabilities, external sources of knowledge, and innovation, but also by shedding light on these relationships which is not investigated by previous research. Rest of the study is organized as follows. After this introduction, in section two the theoretical background is discussed. In the third section the hypotheses and the research model are presented. Section four discusses the methodology and section 5 describes the data analysis and the results. The study ends with conclusion and implications.

\section{LITERATURE SURVEY}

In recent years, since knowledge economies have emerged and technological changes have occurred, innovation became a dominator on competitiveness, development and economic growth of countries. From the firm point of view, innovation which can be defined as the result of the transformation process of new goods and services, and processes in short, supports efficient use of resources and causes a sustainable and competitive market (Crespy et al., 2014).

Innovation could be explained by the inputs or the outputs. Since inputs are defined as the efforts such as new products, new processes, new marketing methods or organizational developments, the first thing that comes to mind for an input is research and development (R\&D) (Mohnen and Hall, 2013). Until the 1980s, innovation process was defined as linear which follows a straight way started with R\&D and ended with the market. This model put R\&D in the center of innovation activities and the innovativeness of a firm was mainly seen as the success of R\&D investments (Svetina and Prodan, 2008). This view called as exploitation and based upon the idea that innovation is the result of the exploitation of internal capabilities. Main critique of this approach is that it could not be sufficient in explaining the innovative success of several small and medium enterprises (SMEs) even they invest less on R\&D activities. After realizing that, another approach called exploration is emerged. This approach emphasizes the importance of external 
sources in innovation (Su et al., 2009) and innovations are seen as the result of using the capabilities and learning. Firms cannot learn by themselves, they learn when they are in communication with each other. Based upon this idea the interactive model of innovation which is based on the knowledge-flows within the organization, and other players in the market is used recently (Svetina and Prodan, 2008).

There are several studies based on the exploitation and exploration approaches in the literature. However they rarely examine the joint effect of the internal capabilities and external sources of knowledge on different types of innovation (Su et al. 2009). These studies have claimed that these sources have significant impact on innovations (Svetina and Prodan, 2008; Su et al., 2009; Vega-Jurado et al., 2009). However the role of firm's internal capabilities in innovations could not be denied but in today's highly global markets internal capabilities are not sufficient to compete and therefore the external sources of knowledge plays a vital role in innovations as well (Arundel and Bordey, 2011; Vega-Jurado et al. 2009). Thus this study attempts to construct an inclusive research framework which integrates both internal capabilities and external sources of knowledge.

Innovation plays a significant role for manufacturing firms in today's highly global and changing business environment. Firms, realizing the importance of innovation, began to use it as a key factor for competitiveness. Schumpeter (1947) makes a broad and remarkable definition of innovation and stated that innovation means new possibilities for additional valued added (Martinez-Ros and Francina Orfila-Sintes, 2009). According to his point of view, introduction of a new product, and a new method of production, opening of a new market, development of new sources of supply for raw materials or other inputs, and creation of new market structures in an industry could be defined as an innovation (Oslo Manual, 2005) but there is a debate in classifying innovation in the literature. While some researchers have made different classifications such as administrative and technical, product and process, technological and architectural (Massa and Testa, 2008), the distinction between product and process is the most used classification. Another aim of this study is to use a broad classification of innovations (output side of innovation). OECD's Oslo Manual (2005) made a broad classification such as product, process, organizational and marketing innovations. These are defined as follows:

- A product innovation is the introduction of a good or service that is new or significantly improved with respect to its characteristics or intended uses. This includes significant improvements in technical specifications, components and materials, incorporated software, user friendliness or other functional characteristics.

- Process innovations can be defined as the implementation of a new or significantly improved production or delivery method. These include significant changes in techniques, equipment and/or software.

- Organizational innovations in business practices involve the implementation of new methods for organizing routines and procedures for the conduct of work.

- A marketing innovation is the implementation of a new marketing method involving significant changes in product design or packaging, product placement, product promotion or pricing. 


\section{HYPOTHESES AND RESEARCH FRAMEWORK}

Several previous studies on innovation have struggled with the measures of innovations. There are generally known measures such as R\&D inputs, patents granted and patents applied the amount of patents and/or new product announcements, etc. In order to manage the shortcomings of using more than one indicator, many studies have focused on one of these indicators and in some cases they have used two or more indicators to generate a construct (Hagedoorn and Cloodt, 2003). In this paper two main constructs including multiple indicators such as R\&D, patents, acquisition of external knowledge, etc. will be used in order to provide a better understanding of sources of innovation.

\subsection{Internal Capabilities and Innovation}

Business management literature deals with identifying the internal sources that affect the firms' innovations (Vega-Jurado et al., 2009; Su et al, 2009, Svetina and Prodan, 2008). They mostly use resource based view and focuse on organizational capabilities which are defined as 'the comprehensive set of capabilities used by the organization in order to facilitate and support the innovation strategies' (Barrett and Sexton, 2006). These capabilities include technological capabilities, human resource capabilities and organizational capabilities. Technological capabilities are generally explained in terms of in-house R\&D activities while human resource capabilities include benefiting from knowledge, skills, training and experience of workers, and finally organizational capabilities are related with administrative style, formalization and work teams (VegaJurado et al. 2009). In the study of Hagedoorn and Cloodt (2003), the main indicators of firms' innovation performance in terms of internal capabilities are classified as R\&D inputs, patent counts, patent citations, and new product announcements. R\&D capability has vital importance in every innovation activity since it provides the firm's ability to generate new products and new technologies. It also supports new product, process, marketing and organizational innovations. Similarly patent citations and patent counts are also accepted as indicators of the innovation performance (Su et al., 2009). In this study a multi-dimensional index covering all of these indicators is generated. Hence, in order to analyze the relationship between the internal and external capabilities and various types of innovations, following hypotheses are drawn up:

Hypothesis 1 - Firms that benefit from internal capabilities is likely to make innovations. Hypothesis $1 a$ - Firms that benefit from internal capabilities is likely to make product innovations.

Hypothesis $1 b$ - Firms that benefit from internal capabilities is likely to make process innovations.

Hypothesis 1c - Firms that benefit from internal capabilities is likely to make organizational innovations.

Hypothesis 1d - Firms that benefit from internal capabilities is likely to make marketing innovations.

\subsection{External Sources of Knowledge and Innovation}


Firms need to acquire external sources of knowledge in order to be innovative. External sources of knowledge could be local, national, and international. As mentioned in the previous section firms have an opportunity to use their internal sources such as in-house R\&D activities, and employee skills but education and training programs and it will be helpful for improving the existing internal sources but in some cases firms may not have appropriate capabilities within the firm. In this case, they can use external sources of knowledge by cooperating with their customers and suppliers, as well as other players in the market, or by using institutions. Firms could also get the knowledge via consultants (Svetina and Prodan, 2008). A multi-dimensional index is generated for external sources of knowledge which is including the indicators shown in Figure 1 and overall the hypothesis stated below is developed.

Hypothesis 2 - Firms that use external sources of knowledge are likely to make innovations.

Hypothesis $2 a$ - Firms that use external sources of knowledge are likely to make product innovations.

Hypothesis $2 b$ - Firms that use external sources of knowledge are likely to make process innovations.

Hypothesis 2c-Firms that use external sources of knowledge are likely to make organizational innovations.

Hypothesis $2 d$ - Firms that use external sources of knowledge are likely to make marketing innovations.

However the above hypotheses are proposed for evaluating the effects of internal capabilities and external sources of knowledge respectively, hypothesis 3 is generated to test the effect of both.

Hypothesis 3 - Firms that benefit from internal capabilities and also use external sources of knowledge are likely to make innovations.

Hypothesis $3 a$ - Firms that benefit from internal capabilities and also use external sources of knowledge are likely to make product innovations.

Hypothesis $3 b$ - Firms that benefit from internal capabilities and also use external sources of knowledge are likely to make process innovations.

Hypothesis $3 c$ - Firms that benefit from internal capabilities and also use external sources of knowledge are likely to make organizational innovations.

Hypothesis $3 d$ - Firms that benefit from internal capabilities and also use external sources of knowledge are likely to make marketing innovations.

The research framework generated based upon the theoretical background is illustrated in Figure 1. 
Figure 1: Research Model of the Study

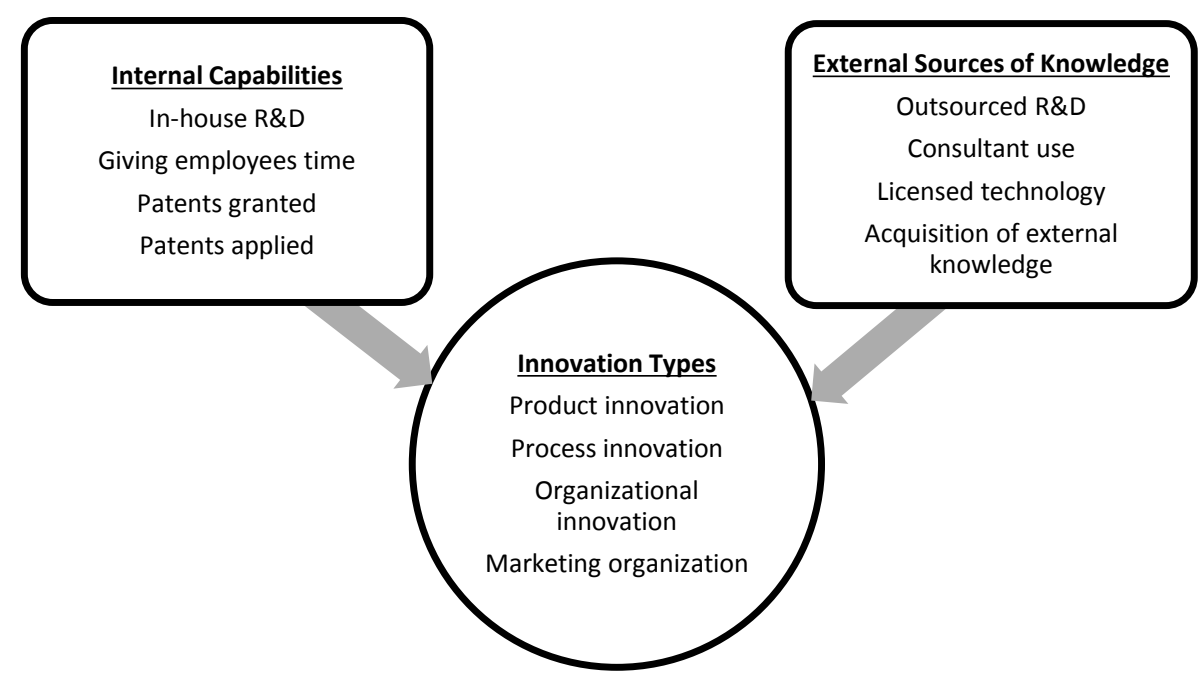

\section{DATA AND METHODOLOGY}

In this section the sample and the data is described first and then the measures of the variables used in the model will be given.

\subsection{Sample and Data}

The hypotheses are tested by utilizing the data in BEEPS conducted by World Bank. The survey provides a wide range of data regarding to financing, laboring, infrastructure, training, innovation, quality, technology related issues. It is a periodic survey, which is last updated in 2013 (The World Bank, 2013). The data used in this study is collected from 1344 Turkish firms in 2013. 1094 of these 1344 firms are operating in manufacturing industry. The main aim of our study is to investigate the effects in manufacturing firms, the data regarding to these 1094 firms are used here.

In some questionnaires there are some missing values due to lack of knowledge, declining to give any response or because of some other reasons. The most common approach to missing data is list-wise deletion which means omitting the cases with missing data and running the analyses on what remains. A total of 709 questionnaires were eliminated due to high percentage of missing values. List-wise deletion often results in a decrease in the sample size but since the sample size is big enough, the sample size is considered satisfactory for subsequent analysis. 
Table 1: Factors, Related Variables and Scales

\begin{tabular}{|c|c|c|}
\hline $\begin{array}{l}\text { Internal } \\
\text { Capabilities }\end{array}$ & Scale & \\
\hline In-house $R \& D$ & $\begin{array}{l}\text { Over the last three years, did this establishment spend on research and } \\
\text { development activities within the establishment? }\end{array}$ & $\begin{array}{l}\text { 1: Yes } \\
0: \text { No }\end{array}$ \\
\hline $\begin{array}{l}\text { Giving employees } \\
\text { time }\end{array}$ & $\begin{array}{l}\text { During the last three years, did this establishment give employees some time } \\
\text { to develop or try out a new approach or new idea about products or } \\
\text { services, business process, firm management, or marketing? }\end{array}$ & $\begin{array}{l}\text { 1: Yes } \\
0: \text { No }\end{array}$ \\
\hline Patents granted & Has this establishment ever been granted a patent? & $\begin{array}{l}\text { 1: Yes } \\
0: \text { No }\end{array}$ \\
\hline Patents applied & $\begin{array}{l}\text { During the last three years, did this establishment apply for a patent or a } \\
\text { trademark? }\end{array}$ & $\begin{array}{l}\text { 1: Yes } \\
0: \text { No }\end{array}$ \\
\hline $\begin{array}{l}\text { External sources } \\
\text { of knowledge }\end{array}$ & Scale & \\
\hline Outsourced R\&D & $\begin{array}{l}\text { Over the last three years, did this establishment spend on research and } \\
\text { development activities contracted with other companies? }\end{array}$ & $\begin{array}{l}\text { 1: Yes } \\
0: \text { No }\end{array}$ \\
\hline Consultant use & $\begin{array}{l}\text { In the last three complete fiscal years, how many times has this } \\
\text { establishment hired an external consultant (such as management consultant, } \\
\text { engineer, architect, accountant)? }\end{array}$ & $\begin{array}{l}\text { 1: Yes } \\
0: \text { No }\end{array}$ \\
\hline $\begin{array}{l}\text { Licensed } \\
\text { technology }\end{array}$ & $\begin{array}{l}\text { Does this establishment use technology licensed from a foreign-owned } \\
\text { company, excluding Office software? }\end{array}$ & $\begin{array}{l}\text { 1: Yes } \\
0: \text { No }\end{array}$ \\
\hline $\begin{array}{l}\text { Acquisition } \\
\text { external } \\
\text { knowledge }\end{array}$ & $\begin{array}{l}\text { Over the last three years, did this establishment spend on the acquisition of } \\
\text { external knowledge? This includes purchase or licensing of patents and non- } \\
\text { patented inventions, know-how and other types of knowledge from other } \\
\text { businesses or organizations. }\end{array}$ & $\begin{array}{l}\text { 1: Yes } \\
0: \text { No }\end{array}$ \\
\hline Innovativeness & Scale & \\
\hline $\begin{array}{l}\text { Product } \\
\text { Innovation }\end{array}$ & $\begin{array}{l}\text { During the last three years, has this establishment introduced new or } \\
\text { significantly improved products or services? Please exclude the simple resale } \\
\text { of new goods purchased from others and changes of a solely aesthetic } \\
\text { nature. }\end{array}$ & $\begin{array}{l}\text { 1: Yes } \\
0: \text { No }\end{array}$ \\
\hline $\begin{array}{l}\text { Process } \\
\text { innovation }\end{array}$ & $\begin{array}{l}\text { During the last three years, has this establishment introduced any new or } \\
\text { significantly improved methods for the production or supply of products or } \\
\text { services? }\end{array}$ & $\begin{array}{l}\text { 1: Yes } \\
0: \text { No }\end{array}$ \\
\hline $\begin{array}{l}\text { Organizational } \\
\text { Innovation }\end{array}$ & $\begin{array}{l}\text { During the last three years, has this establishment introduced any new or } \\
\text { significantly improved organizational or management practices or } \\
\text { structures? }\end{array}$ & $\begin{array}{l}\text { 1: Yes } \\
0: \text { No }\end{array}$ \\
\hline $\begin{array}{l}\text { Marketing } \\
\text { Innovation }\end{array}$ & $\begin{array}{l}\text { During the last three years, has this establishment introduced new or } \\
\text { significantly improved marketing methods? }\end{array}$ & $\begin{array}{l}\text { 1: Yes } \\
0: \text { No }\end{array}$ \\
\hline
\end{tabular}

\subsection{Measurement of Variables}

In our model the dependent variable innovation refers the innovation types. As seen from the figure 1, there are two independent variables namely internal capabilities and external sources of knowledge. Internal capabilities and external sources of knowledge are variables which are the aggregation of the items used in measuring them (see Table 1). When aggregating these variables, the default action is performed and the items are summarized by calculating the mean value. Firm age and firm size are included in the model as control variables. Firm age is calculated by the number of years since founding 
and firm size is determined according to the number of employees in four intervals: micro, small, medium and large.

\section{EMPIRICAL FINDINGS}

The sample consists of firms from a wide variety of industries. Most of the firms (23.12\%) are operating in textile industry. Firm age distribution shows that $35.58 \%$ of the firms have been operating from ten to nineteen years and the distribution of firm size emphasize that the sample consist of mostly medium and large-sized firms. Table 2 illustrates the frequency distribution of the sample firms.

Table 2: Demographic Characteristics of Sample

\begin{tabular}{|c|c|c|}
\hline Industry & Frequency & Percent \\
\hline Textiles & 89 & 23.12 \\
\hline Non-metallic mineral products & 85 & 22.08 \\
\hline Chemicals & 70 & 18.18 \\
\hline Garments & 64 & 16.62 \\
\hline Food & 31 & 8.05 \\
\hline Fabricated metal products & 27 & 7.01 \\
\hline Machinery and equipment & 5 & 1.30 \\
\hline Furniture & 4 & 1.04 \\
\hline Motor vehicles & 3 & 0.78 \\
\hline Plastics \& rubber & 2 & 0.52 \\
\hline Tanning \& leather & 1 & 0.26 \\
\hline Wood & 1 & 0.26 \\
\hline Electronics & 1 & 0.26 \\
\hline Construction & 1 & 0.26 \\
\hline Paper \& paper products & 1 & 0.26 \\
\hline Firm Age & Frequency & Percent \\
\hline $0-9$ years & 81 & 21.04 \\
\hline $10-19$ years & 137 & 35.58 \\
\hline $20-29$ years & 74 & 19.22 \\
\hline $30-39$ years & 45 & 11.69 \\
\hline 40-49 years & 27 & 7.01 \\
\hline 50 and more years & 13 & 3.38 \\
\hline Don't know & 8 & 2.08 \\
\hline Firm size & Frequency & Percent \\
\hline Micro Sized Enterprises & 25 & 6.49 \\
\hline Small Sized Enterprises & 60 & 15.58 \\
\hline Medium Sized Enterprises & 194 & 50.39 \\
\hline Large Sized Enterprises & 106 & 27.53 \\
\hline Total & 385 & 100 \\
\hline
\end{tabular}

Since the dependent variable is a yes/no (1/0) question which means it is a dichotomous variable, logistic regression analysis which is an optimal method for the regression analysis of dichotomous (binary) dependent variables is used (Allison, 2012). Before giving the results of logistic regression analysis, descriptive statistics including means, standard deviations and correlation coefficients of the variables are presented in Table 3. As seen from this table, results show strong, positive, and significant correlations between all structural constructs, thus supporting the hypotheses of the study. 
Table 3: Means, Standard Deviations, Correlations

\begin{tabular}{lllllllll}
\hline Variable & Mean & S. D. & $\mathbf{1}$ & $\mathbf{2}$ & $\mathbf{3}$ & $\mathbf{4}$ & $\mathbf{5}$ & $\mathbf{6}$ \\
\hline Product innovation & 0.31 & 0.464 & 1 & & & & & \\
Process innovation & 0.24 & 0.425 & $0.563^{* *}$ & 1 & & & & \\
Organizational innovation & 0.25 & 0.433 & $0.286^{* *}$ & $0.442^{* *}$ & 1 & & & \\
Marketing innovation & 0.27 & 0.443 & $0.341^{* *}$ & $0.451^{* *}$ & $0.425^{* *}$ & 1 & & \\
Internal capabilities & 0.49 & 0.301 & $0.197^{* *}$ & $0.188^{* *}$ & $0.241^{* *}$ & $0.271^{* *}$ & 1 & \\
External sources of knowledge & 0.32 & 0.254 & $0.188^{* *}$ & $0.118^{*}$ & $0.154^{* *}$ & $0.110^{*}$ & $0.378^{* *}$ & 1 \\
\hline
\end{tabular}

Table 4 illustrates the results of logistic regression analysis. In this analysis we use four different types of model in each innovation categories. Models 1, 5, 9 and 13 are the baseline models including only the control variables. According to the results it can be said that industry is significant in the expected direction for product, organizational, and marketing innovations whereas it is not significant for process innovations. While firm size is found significant for product and process innovations, there is not a significant evidence for other types of innovation. It is interesting that we couldn't find any significant influence of firm age on the product, process, organizational and marketing innovations.

Table 4: Results of Logistic Regression Analysis

\begin{tabular}{|c|c|c|c|c|c|c|c|c|}
\hline \multirow[t]{2}{*}{ Variable } & \multicolumn{4}{|c|}{ Product Innovation } & \multicolumn{4}{|c|}{ Process Innovations } \\
\hline & Model 1 & Model 2 & Model 3 & Model 4 & Model 5 & Model 6 & Model 7 & Model 8 \\
\hline $\begin{array}{l}\text { Internal } \\
\text { capabilities }\end{array}$ & & $2.152 * * *$ & & $1.792 * * *$ & & $2.343 * * *$ & & $2.175^{* * *}$ \\
\hline $\begin{array}{l}\text { External } \\
\text { sources of } \\
\text { knowledge }\end{array}$ & & & $1.903 * * *$ & $1.225 * * *$ & & & $1.363 * * *$ & 0.571 \\
\hline Industry & $0.235^{* * *}$ & $0.222 * * *$ & $0.223 * * *$ & $0.212 * * *$ & 0.090 & 0.070 & 0.070 & 0.063 \\
\hline Firm size & $-0.566 * * *$ & $-0.769 * * *$ & $-0.658 * * *$ & $-0.798 * * *$ & $-0.763 * * *$ & $-0.979 * * *$ & $-0.817 * * *$ & $-0.986 * * *$ \\
\hline Firm age & 0.000 & 0.003 & 0.002 & 0.004 & 0.003 & 0.007 & 0.005 & 0.008 \\
\hline $\begin{array}{l}\mathrm{R}^{2} \\
\text { (Nagelkerke) }\end{array}$ & 0.168 & 0.247 & 0.217 & 0.263 & 0.136 & 0.224 & 0.161 & 0.228 \\
\hline $\begin{array}{l}\mathrm{R}^{2} \\
\text { (Cox\&Snell) }\end{array}$ & 0.119 & 0.175 & 0.154 & 0.187 & 0.091 & 0.149 & 0.107 & 0.151 \\
\hline$-2 \mathrm{LL}$ & 428.811 & 403.496 & 431.172 & 397.991 & 384.458 & 358.932 & 377.355 & 357.870 \\
\hline$x^{2}$ & 48.932 & 74.246 & 64.571 & 79.751 & 36.618 & 62.144 & 43.721 & 63.206 \\
\hline \multirow[t]{2}{*}{ Variable } & \multicolumn{4}{|c|}{ Organizational Innovation } & \multicolumn{4}{|c|}{ Marketing Innovation } \\
\hline & Model 9 & Model 10 & Model 11 & Model 12 & Model 13 & Model 14 & Model 15 & Model 16 \\
\hline $\begin{array}{l}\text { Internal } \\
\text { capabilities }\end{array}$ & & $2.144^{* * *}$ & & $1.963 * * *$ & & $2.482^{* * *}$ & & $2.474 * * *$ \\
\hline $\begin{array}{l}\text { External } \\
\text { sources of } \\
\text { knowledge }\end{array}$ & & & $1.326^{* *}$ & 0.591 & & & $0.956 * *$ & 0.024 \\
\hline Industry & $0.182^{* *}$ & $0.165 * *$ & $0.165^{* *}$ & $0.158 * *$ & $0.112 * *$ & 0.090 & $0.098^{*}$ & 0.089 \\
\hline Firm size & 0.037 & -0.134 & -0.020 & -0.148 & -0.119 & $-0.326 * *$ & -0.158 & $-0.326 * *$ \\
\hline Firm age & 0.004 & 0.008 & 0.006 & 0.009 & 0.000 & 0.004 & 0.002 & 0.004 \\
\hline $\mathrm{R}^{2}$ (Nagelkerke) & 0.043 & 0.131 & 0.072 & 0.136 & 0.026 & 0.144 & 0.041 & 0.144 \\
\hline $\mathrm{R}^{2}$ (Cox\&Snell) & 0.029 & 0.089 & 0.048 & 0.092 & 0.018 & 0.099 & 0.028 & 0.099 \\
\hline$-2 \mathrm{LL}$ & 421.051 & 396.678 & 413.314 & 395.390 & 440.386 & 407.021 & 436.121 & 407.019 \\
\hline$x^{2}$ & 11.397 & 35.770 & 19.134 & 37.058 & 6.821 & 40.187 & 11.086 & 40.189 \\
\hline
\end{tabular}

Models 2, 6, 10 and 14 include internal capabilities. Based upon the Table 4, it can be said that since the coefficients of internal capabilities in these models are significant and positive; Hypothesis 1a, 1b, 1c, and 1d are supported. Model 3, 7, 11, and 15 investigate the effect of external sources of knowledge on innovation and the results indicate that firms using external sources of knowledge are likely to have innovations (product, process, organizational and marketing innovations). Thus Hypothesis $2 a, 2 b, 2 c$, and $2 d$ are 
supported. But the results illustrated in Model 4, 812 and 16 indicate something different. In these models, the joint effect of internal capabilities and external sources is tested and only the hypothesis related with product innovation is accepted. According to the results it can be said that only Hypothesis $3 a$ is supported which in turn means Hypothesis 3 is partially supported.

\section{CONCLUSION}

This paper has reported and discussed the findings of a study in Turkish manufacturing industry drawing a model which links internal capabilities, external sources of knowledge, and innovation.

The theoretical framework is empirically tested with the data gathered from the BEEPS. The paper not only tests the linkages solely but it also points out the importance of joint effort of internal capabilities and external sources of knowledge in the innovation process. This study also treats innovations from a broader perspective and the innovation term refers product, process, organizational and marketing innovations.

The findings support the claim that firms benefited from internal capabilities are likely to make innovations, and firms that benefited from external sources of knowledge are likely to make innovations as well. However the joint effect of both has a positive and significant effect only on product innovations. The linkages between the joint effect of internal capabilities and external sources of knowledge, and the process, organizational and marketing innovations are not found to be significant. In Turkey innovation activities gain more importance day by day and firms see innovations as a tool for maintaining or increasing their competitive power and their survival. Firms see R\&D activities as the most important tool for innovations and they acquire new and successful products when they invest R\&D activities. Thus product innovations are appeared as a critical driver of competitiveness in Turkish manufacturing firms. Product innovations also enable process innovations in most cases but especially in emerging countries manufacturing firms have difficulties in adopting process innovations easily. When we compare the Turkish manufacturing system to other emerging countries, it is obvious that she has a wellorganized system but the country's capability of innovativeness is still very low when compared to developed countries. On the other hand since these firms are still using lowlabor cost advantage it is necessary for them to consider "being innovative" in the global and competitive market.

The findings are important for Turkish firms and policy makers and they may see the importance of the joint effect of internal capabilities and external sources of knowledge in increasing of the firms' success and competitiveness.

Although the study has found significant results using both internal capabilities and external sources of knowledge for innovativeness, the issue still needs some more research. First, considering that this study is based upon the data on a single country Turkey, future studies could include two or more countries in order to make a comparison. Since Turkey is an emerging country, comparison can also be conducted in developed countries in order to see the differences. For each construct certain variables are identified but in order to investigate the relations deeply, other variables used in different 
studies could be added. In addition to using survey data, future research could employ indepth interviews to enhance the quality of the results.

\section{REFERENCES}

Allison, P. D. (2012). Logistic regression using SAS: Theory and application. $2^{\text {nd }}$ ed. Cary: N.C.: SAS Institute.

Arundel, A. \& Bordoy, C. (2001). The relative value of internal and external information sources to innovation. In Know for innovation workshop, Athens.

Barrett, P. and Sexton. M. (2006). Innovation in small, project-based ccnstruction firms, British Journal of Management, 17 (4), pp. 331-346.

Chesbrough, H. (2003). The era of open innovation, Sloan Management Review, 44 (3), pp. 35-41.

Cohen, W. M., \& Levinthal, D. A. (1990). Absorptive capacity: a new perspective on learning and innovation. Administrative science quarterly, 128-152.

Crespi, G., Arias-Ortiz, E., Tacsir, E., Vargas, F., \& Zuñiga, P. (2014). Innovation for economic performance: the case of Latin American firms. Eurasian Business Review, 4 (1), pp. 31-50.

Dosi, G. (1982). Technological paradigms and technological trajectories: a suggested interpretation of the determinants and directions of technical change. Research Policy, 11 (3), pp. 147-162.

Hagedoorn, J. and Myriam C. (2003). Measuring innovative performance: is there an advantage in using multiple indicators?. Research policy, 32 (8), pp. 1365-1379.

Lokshin, B., Belderbos, R. \& Carree, M. (2008). The productivity effects of internal and external R\&D: evidence from a dynamic panel data model. Oxford Bulletin of Economics and Statistics, 70 (3), pp. 399-413.

March, J. G. (1991). Exploration and exploitation in organizational learning. Organization Science, 2 (1), pp. 71-87.

MartÍnez-Ros, E. and Orfila-Sintes, F. (2009). Innovation activity in the hotel industry. Technovation, 29 (9), pp. 632-641.

Massa, S., and Testa. S. (2008). Innovation and SMEs: Misaligned perspectives and goals among entrepreneurs, academics, and policy makers. Technovation 28 (7), pp. 393-407.

Mohnen, P., \& Hall, B. H. (2013). Innovation and productivity: an update. Eurasian Business Review, 3 (1), pp. 4765.

Oslo Manual, $\quad 3^{\text {rd }} \quad$ ed. (2005), http://www.tubitak.gov.tr/tubitak_content_files/BTYPD/kilavuzlar/Oslo_Manual_Third_Edition.pdf (Accessed July 1, 2015).

Schumpeter, J. A. (1947). The creative response in economic history. The Journal of Economic History, 7 (2), pp. 149-159.

Su, Y., Tsang, E. W., \& Peng, M. W. (2009), How do internal capabilities and external partnerships affect innovativeness? Asia Pacific Journal of Management, 26 (2), pp. 309-331.

Svetina, A. C., \& Prodan. I. (2008). How internal and external sources of knowledge contribute to firms' innovation performance. Managing Global Transitions, 6 (3), pp. 277-299.

The World Bank, 2013. Business Environment and Enterprise Performance Survey. Business Environment and Enterprise Performance Survey. http://data.worldbank.org/data-catalog/BEEPS (December 12, 2014).

Vega-Jurado, J., Gutiérrez-Gracia, A. \& Fernández-de-Lucio, I. (2009). Does external knowledge sourcing matter for innovation? Evidence from the Spanish manufacturing industry, Industrial and Corporate Change, 18 (4), pp. 637-670.

Von Hippel, E. (1988), The sources of innovation. New York: Oxford University Press. 